\title{
Mechanism of DNA Cleavage Induced by $\mathrm{Fe}^{2+}$ Autoxidation
}

\author{
Jong Moon Kim and Seog K. Kim* \\ Department of Chemistry, Yeungnam University, Gyeong-buk 712-749, Korea. EE-mail: seogkim@yumail.ac.kr \\ Received December 23, 2010, Accepted January 19, 2011
}

\begin{abstract}
This work investigated the difference between $\mathrm{Fe}^{2+}$ autoxidation-induced and Fenton-type cleavage of pBR322 plasmid DNA. ${ }^{\circ} \mathrm{OH}$ generation reactions in the absence and presence of $\mathrm{H}_{2} \mathrm{O}_{2}$ under various conditions were also investigated. Although both the $\mathrm{Fe}^{2+}$ autoxidation and Fenton-type reactions showed DNA cleavage and $\cdot \mathrm{OH}$ generation, there were significant differences in their efficiencies and reaction rates. The rate and efficiency of the cleavage reaction were higher in the absence of $1.0 \mathrm{mM}$ of $\mathrm{H}_{2} \mathrm{O}_{2}$ than in its presence in $20 \mathrm{mM}$ phosphate buffer. In contrast, the ${ }^{\circ} \mathrm{OH}$ generation reaction was more prominent in the presence of $\mathrm{H}_{2} \mathrm{O}_{2}$ and showed a pH-independent, fast initial reaction rate, but the rate was decreased in the absence of $\mathrm{H}_{2} \mathrm{O}_{2}$ at across the entire tested $\mathrm{pH}$ range. Studies using radical scavengers on DNA cleavage and ${ }^{\circ} \mathrm{OH}$ generation reactions in both the absence and presence of $\mathrm{H}_{2} \mathrm{O}_{2}$ confirmed that both reactions spontaneously involved the active oxygen species ${ }^{\circ} \mathrm{OH}, \mathrm{O}_{2}{ }^{--},{ }^{1} \mathrm{O}_{2}$ and $\mathrm{H}_{2} \mathrm{O}_{2}$, indicating that a similar process may participate in both reactions. Based on the above observations, a new mechanism for the $\mathrm{Fe}^{2+}$ autoxidation-induced DNA cleavage reaction is proposed.
\end{abstract}

Key Words : Iron autoxidation, Fenton reaction, Reactive oxygen species, Hydroxyl radical

\section{Introduction}

Reduced iron ions are toxic. They damage various biomolecules due to their ability to produce reactive oxygen species (ROS). Living organisms utilize proteins such as transferrin and ferritin to store labile iron ions and thereby avoid accumulation of excess iron ions. ${ }^{1,2}$ The concentration of $\mathrm{Fe}^{2+}$ ions in cells is increased under stress, thus inflicting oxidative damage on various biomolecules, including proteins, DNA, lipids and tissue cells. ${ }^{3,4}$ Of all ROS induced by $\mathrm{Fe}^{2+}$, the causative agent of DNA damage is believed to be the ${ }^{\circ} \mathrm{OH} .^{5-8}$

It has been proposed that free $\mathrm{Fe}^{3+}$, once bound adventitiously to DNA, can be reduced by superoxide radical, $\mathrm{O}_{2}{ }^{--}$ (Eq. 1). ${ }^{9}$ Subsequently, highly reactive ${ }^{\circ} \mathrm{OH}$ is generated upon interaction with endogenously produced hydrogen peroxide $\left(\mathrm{H}_{2} \mathrm{O}_{2}\right)$ under Fenton conditions (Eq. 2). ${ }^{10-13}$ In addition, it is also proposed that excess hydrogen peroxide could scavenge ${ }^{\circ} \mathrm{OH}$ as in Eq. (3). ${ }^{8}$

$$
\begin{aligned}
& \mathrm{O}_{2}^{\cdot-}+\mathrm{Fe}^{3+} \rightarrow \mathrm{O}_{2}+\mathrm{Fe}^{2+} \\
& \mathrm{H}_{2} \mathrm{O}_{2}+\mathrm{Fe}^{2+} \stackrel{\mathrm{H}^{+}}{\longrightarrow} \mathrm{Fe}^{3+}+\mathrm{OH}^{\cdot}+\mathrm{H}_{2} \mathrm{O} \\
& \cdot \mathrm{OH}+\mathrm{H}_{2} \mathrm{O}_{2} \rightarrow \mathrm{HO}_{2}{ }^{\cdot}+\mathrm{H}_{2} \mathrm{O}
\end{aligned}
$$

The kinetics of $\mathrm{Fe}^{2+}$ oxidation is very slow but it can be readily oxidized to $\mathrm{Fe}^{3+}$ in response to complex formation with chemicals containing phosphate moiety, e.g., pyrophosphate, polyphosphate, DNA, and nucleotides in the dior triphosphate form. ${ }^{14-18}$ Additionally, several studies have identified the production of superoxide and ${ }^{\circ} \mathrm{OH}$ as a result of the oxidation of $\mathrm{Fe}^{2+}$ in which molecular oxygen is involved instead of $\mathrm{H}_{2} \mathrm{O}_{2}$. ${ }^{18,19}$

On the other hand, some reports have proposed the generation of reactive ${ }^{\circ} \mathrm{OH}$ mainly by the direct interaction between metal ions and molecular oxygen, rather than the Fenton reaction. Such an interaction produces a highly reactive iron-oxygen complex, for instance ferryl- or perferryl- complexes (Eqs. 4. and 5), that equals or surpasses the oxidizing potential of the ${ }^{\circ} \mathrm{OH} .{ }^{8,20-22}$

$$
\begin{aligned}
& \mathrm{Fe}^{2+}+\mathrm{O}_{2} \rightarrow\left[\mathrm{Fe}^{2+}-\mathrm{O}_{2} \rightarrow \mathrm{Fe}^{3+}-\mathrm{O}_{2}{ }^{-}\right] \rightarrow \\
& \mathrm{Fe}^{2+}-\mathrm{Fe}_{2}+\mathrm{Fe}^{2+}+\mathrm{O}_{2}{ }^{--} \\
& \text {(Perferryl ion) }
\end{aligned}
$$

Recently, Flemmig and Arnhold observed that $\mathrm{Fe}^{2+}$ induced pBR322 plasmid DNA cleavage was affected by the nature of buffer components; phosphate buffer produced higher cleavage efficiency than bicarbonate did. Some component in the buffer solution was proposed to bind to $\mathrm{Fe}^{2+}$ and influence its autoxidation ability. ${ }^{23}$ Cleavage efficiency was attenuated by the addition of superoxide dismutase (SOD). Therefore, it was also suggested that a superoxide radical is somehow involved in the cleavage reaction.

These alternative mechanisms were proposed based on the fact that the Fenton reaction is an insufficient source for ${ }^{\circ} \mathrm{OH}$ due to the low concentration of physiological $\mathrm{H}_{2} \mathrm{O}_{2}$, which is approximately $10^{-10} \mathrm{M}$ in red blood cells ${ }^{24}$ and $10^{-8} \mathrm{M}$ in the inner mitochondrial membrane ${ }^{25}$ and liver cells. ${ }^{26}$ Additional evidence supporting this process is observed in the rate constants for the oxidation of $\mathrm{Fe}^{2+}$ by $\mathrm{O}_{2}{ }^{--}$and of the Fenton reaction, which are estimated to be $10^{6}-10^{7} \mathrm{M}^{-1} \mathrm{~s}^{-1}$ and $10^{3}-$ $10^{5} \mathrm{M}^{-1} \mathrm{~s}^{-1}$, respectively. These physiological $\mathrm{H}_{2} \mathrm{O}_{2}$ concentrations are insufficient for the initiation of the Fenton reaction ${ }^{27,28}$ although the rate constants for the generation of 'OH by $\mathrm{Fe}^{2+}-\mathrm{O}_{2}$ and $\mathrm{Cu}^{+}-\mathrm{O}_{2}$ complexes are comparable to that of the $\mathrm{Fe}^{2+}$-driven Fenton reaction. ${ }^{21}$

Although $\mathrm{H}_{2} \mathrm{O}_{2}$ is most likely the major promoter of DNA 
damage, the exact nature of $\mathrm{Fe}^{2+}$-induced DNA cleavage is still a matter of debate. In order to understand the characteristics of metal ion-induced DNA cleavage, we investigated the effects of $\mathrm{pH}$, buffer components, and radical scavengers on the $\mathrm{Fe}^{2+}$-mediated cleavage of pBR322 plasmid and ${ }^{\circ} \mathrm{OH}$ generation reactions in the absence and presence of $\mathrm{H}_{2} \mathrm{O}_{2}$. Based on our results, we propose a new mechanism for the $\mathrm{Fe}^{2+}$ autoxidation-induced DNA cleavage reaction.

\section{Materials and Methods}

Materials. The pBR322 plasmid DNA stock solution $(1.0 \mathrm{mg} / \mathrm{mL})$ containing $10 \mathrm{mM}$ Tris- $\mathrm{HCl}$ and $1.0 \mathrm{mM}$ EDTA at pH 8.0 was purchased from New England Biolabs (Massachusetts, USA). Calf-thymus DNA (ctDNA) was purchased from Worthington Biochemicals (New Jersey, USA) and was dissolved in the required buffers containing $100 \mathrm{mM} \mathrm{NaCl}$ and $1.0 \mathrm{mM}$ EDTA by exhaustive stirring at $4{ }^{\circ} \mathrm{C}$. Dissolved DNA was dialyzed several times at $4{ }^{\circ} \mathrm{C}$ against the required buffers. The ctDNA concentration was determined spectrophotometrically using the absorption coefficient, $\varepsilon_{260 \mathrm{~nm}}=6700 \mathrm{M}^{-1} \mathrm{~cm}^{-1}$. $\mathrm{FeCl}_{2}$, glycerol, $\mathrm{H}_{2} \mathrm{O}_{2}$, SOD from E. coli, bovine liver catalase, and terephthalic acid (TPA) were obtained from Sigma-Aldrich (St. Louis, MO, USA). Stock solutions of $\mathrm{FeCl}_{2}$ in distilled water were prepared immediately prior to use. The $\mathrm{H}_{2} \mathrm{O}_{2}$ concentration was determined using a spectrophotometer at $\varepsilon_{230 \mathrm{~nm}}=$ $74 \mathrm{M}^{-1} \mathrm{~cm}^{-1}{ }^{29}$ Buffer solutions with different $\mathrm{pHs}$ were prepared by mixing the same concentrated acidic and basic forms until the required $\mathrm{pH}$ was obtained.

Cleavage of pBR322 Plasmid DNA with Iron Ion. The pBR322 plasmid DNA was diluted to a final concentration of $100 \mathrm{ng} / \mu \mathrm{L}$ with the required buffer solutions. The reaction mixture $(12 \mu \mathrm{L})$ consisted of $200 \mathrm{ng}$ of pBR322 plasmid DNA and $\mathrm{FeCl}_{2}$ mixed in $20.0 \mathrm{mM} \mathrm{NaH} \mathrm{PO}_{4}$ buffer at $\mathrm{pH}$ 7.0 , unless otherwise indicated. Since preparation order is crucial, the metal ion was always added last. After incubation at the required temperature, a $4 \mathrm{~mL}$ solution comprised of $50 \%$ glycerol $(\mathrm{v} / \mathrm{v}), 40 \mathrm{mM}$ EDTA, $0.025 \%$ bromophenol blue and $0.025 \%$ Xylene cyanol FF was added to stop the reaction. The reaction mixtures were then subjected to $1 \%$ agarose gel electrophoresis. The samples were placed in a horizontal slab gel apparatus in TAE buffer ( $40 \mathrm{mM}$ Tris, 20 $\mathrm{mM}$ sodium acetate and $2 \mathrm{mM}$ EDTA) set at $20 \mathrm{~V}$ for 12 hours. The gel was stained with ethidium bromide for 15 minutes followed by destaining in TAE buffer for 2-3 hours. Finally, the gels were photographed using a UV transilluminator.

Quantification of DNA Cleavage Efficiency. The integrated densities of the bands indicating pBR322 plasmid DNA in each lane were quantified by Total Lab TL100 image analysis software (Nonlinear Dynamic Ltd., USA). Since the lower binding constants of ethidium bromide to the supercoiled form, open circular and linear DNA were all comparable, the intensities of the supercoiled DNA were corrected by a factor of $1.4 .^{30}$
Fluorescence Detection of 'OH Generation. Hydroxylation of non-fluorescent TPA yields 2-hydroxy-terephthalate which emits strong fluorescence around $430 \mathrm{~nm}$ when excited at $323 \mathrm{~nm}$. TPA was dissolved in the required phosphate buffer to make a $10 \mathrm{mM}$ stock solution and was diluted to a final concentration of $400 \mu \mathrm{M}$. All spectral measurements were performed after completion of the reaction at $37{ }^{\circ} \mathrm{C}$. Time-dependent measurements were performed at room temperature and were started by the addition of $\mathrm{FeCl}_{2}$. A Jasco FP-777 fluorimeter was used for all measurements with $5 / 5 \mathrm{~nm}$ of excitation and emission slit widths. Emission spectra were obtained with the excitation at $323 \mathrm{~nm}$ and time-dependent intensity was measured at $426 \mathrm{~nm}$.

\section{Results}

$\mathrm{Fe}^{2+}$-induced pBR322 Plasmid DNA Cleavage in the Presence and Absence of $\mathrm{H}_{2} \mathrm{O}_{2} . \mathrm{Fe}^{2+}$ ion-mediated pBR322 plasmid DNA cleavage in the absence and presence of $\mathrm{H}_{2} \mathrm{O}_{2}$ are compared in Figure 1. Untreated plasmid DNA exhibited two bands; one corresponding to a circular supercoiled form with high electrophoretic mobility and the other to an open circular form with reduced mobility. The amount of supercoiled DNA bands was calculated to be $93.5 \%$ and $6.5 \%$ of the nicked circular form. The $\mathrm{Fe}^{2+}$-induced supercoiled DNA cleavage clearly exhibited much higher efficiency in the absence of $\mathrm{H}_{2} \mathrm{O}_{2}$ than in its presence (Figure 1(a)). In the absence of $\mathrm{H}_{2} \mathrm{O}_{2}$, supercoiled DNA almost completely converted to the nicked circular form within 30 minutes in the $\mathrm{Fe}^{2+}$ concentration as low as $50 \mu \mathrm{M}$. The band analysis showed that $88.2 \%$ of the nicked circular and $2.7 \%$ of the linear form were generated while $9.1 \%$ of the supercoiled from remained. Above $50 \mu \mathrm{M}$ of $\mathrm{Fe}^{2+}$, the supercoiled form

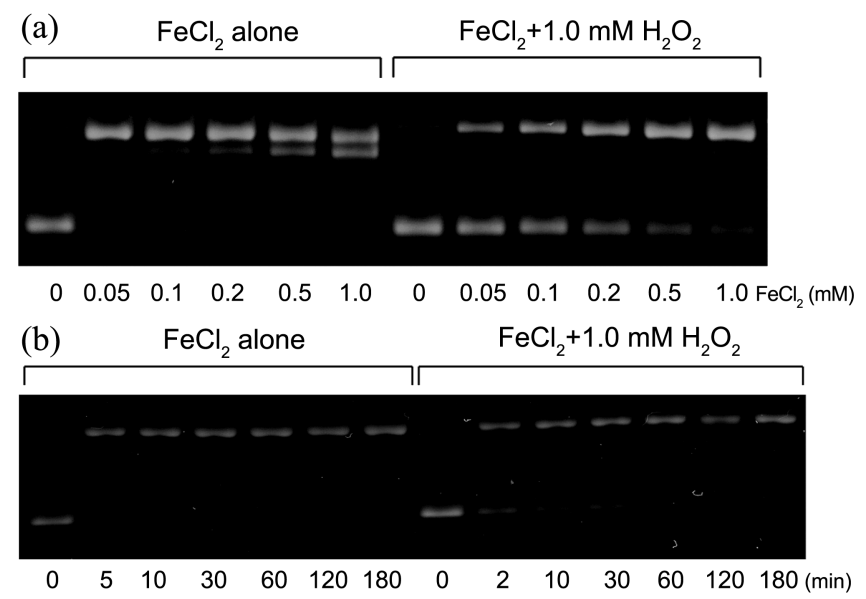

Figure 1. Effect of $\mathrm{H}_{2} \mathrm{O}_{2}$ on $\mathrm{Fe}^{2+}$-induced pBR322 plasmid DNA cleavage. Plasmid DNA (200 ng) was treated in $20 \mathrm{mM}$ phosphate buffer, pH 7.0 with or without $1.0 \mathrm{mM}$ of $\mathrm{H}_{2} \mathrm{O}_{2}$. (a) $\mathrm{FeCl}_{2}$ concentration was increased as indicated in the absence and presence of $1.0 \mathrm{mM} \mathrm{H} \mathrm{H}_{2} \mathrm{O}_{2}$. The sample was incubated for 30 minutes at $37^{\circ} \mathrm{C}$. (b) Time-dependent cleavage of pBR322 plasmid DNA at a fixed concentration of $0.1 \mathrm{mM}$ of $\mathrm{FeCl}_{2}$ in the presence and absence of $\mathrm{H}_{2} \mathrm{O}_{2}$. The sample was incubated in iced water. 
(a)

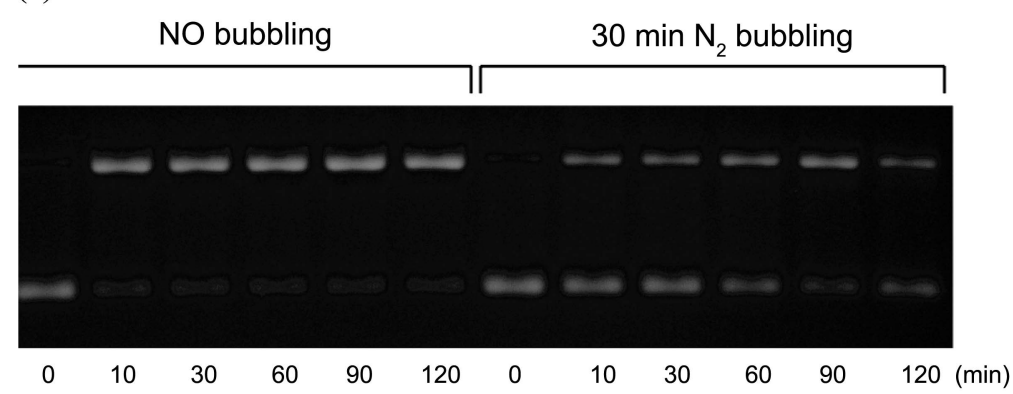

(b) 100

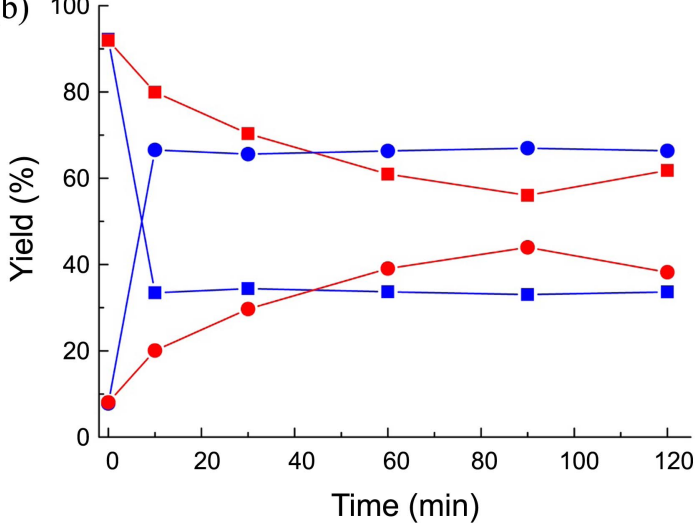

Figure 2. (a) Effect of $\mathrm{N}_{2}$ bubbling on the $\mathrm{Fe}^{2+}$-induced pBR322 plasmid DNA cleavage in the presence of $0.1 \mathrm{mM} \mathrm{FeCl} 2$ in $20 \mathrm{mM}$ phosphate buffer, at $\mathrm{pH} 7.0$ and $37^{\circ} \mathrm{C}$. The sample was gently bubbled by pure $\mathrm{N}_{2}$ gas for 30 minutes. (b) The DNA bands of supercoiled (square) and nicked (circle) forms were quantified and plotted against reaction time with (blue line) and without (red line) $\mathrm{N}_{2}$ bubbling.

was completely disappeared. The generation of the linear form increased gradually with increasing $\mathrm{Fe}^{2+}$ concentration, and finally band smearing appeared at $1.0 \mathrm{mM} \mathrm{Fe}{ }^{2+}$, indicating that the linearized form was converted to shorter DNA fragments. On the other hand, the presence of $1.0 \mathrm{mM}$ of $\mathrm{H}_{2} \mathrm{O}_{2}$ alleviated the cleavage efficiency compared to that in the absence of $\mathrm{H}_{2} \mathrm{O}_{2}$. The time-dependent pBR322 plasmid DNA cleavage in the absence and presence of 1.0 $\mathrm{mM} \mathrm{H}_{2} \mathrm{O}_{2}$ are compared in Figure 1(b). Both reactions were carried out in ice since the reactions were too fast at higher temperatures. Comparing the two reactions, $\mathrm{Fe}^{2+}$ exhibited faster cleavage reaction in the absence of $\mathrm{H}_{2} \mathrm{O}_{2}$ than in its presence. The supercoiled form completely disappeared within 5 minutes in the absence of $\mathrm{H}_{2} \mathrm{O}_{2}$ while it was remained up to 1 hour in the presence of $\mathrm{H}_{2} \mathrm{O}_{2}$. Whether the mechanism behind the cleavage in the presence and absence of $\mathrm{H}_{2} \mathrm{O}_{2}$ is the same or different, it is clear that $\mathrm{Fe}^{2+}$-induced DNA cleavage does not require the presence of exogenous $\mathrm{H}_{2} \mathrm{O}_{2}$.

Contribution of $\mathrm{O}_{2}$ in the $\mathrm{Fe}^{2+}$-mediated Plasmid DNA Cleavage. For the Fenton reaction, $\mathrm{H}_{2} \mathrm{O}_{2}$ is the source of reactive ${ }^{\circ} \mathrm{OH}$ as shown in Eq. (2). However, it is possible that the oxygen molecules dissolved in aqueous solution are the molecular source for the synthesis of ROS in the absence of $\mathrm{H}_{2} \mathrm{O}_{2}$ (Figure 1). Hence, we tested the role of dissolved oxygen by comparing the extent of cleavage with or without nitrogen bubbling. As shown in Figure 2(a), supercoiled pBR322 plasmid DNA began being converted to an open circular form by $0.1 \mathrm{mM} \mathrm{Fe}^{2+}$ ions within 10 minutes. After 120 minutes of mixing, about $65 \%$ of the supercoiled form was cleaved. The residual nicking seems to be due to the trace of oxygen molecules. However, the removal of dissolved oxygen molecules by nitrogen bubbling significantly reduced the DNA cleavage efficiency; $35 \%$ of plasmid DNA was cleaved after 120 minutes, a percentage almost twice than that of the non- $\mathrm{N}_{2}$ bubbled reaction. This result suggests that dissolved oxygen molecules participate in $\mathrm{Fe}^{2+}$ induced DNA cleavage in the absence of $\mathrm{H}_{2} \mathrm{O}_{2}$. Considering the time-dependent curve of the cleavage product in Figure 2(b), $\mathrm{Fe}^{2+}$ induced faster and more efficient cleavage reaction with the help of dissolved oxygen molecules: the cleavage reaction was completed within 10 minutes. In contrast, in the presence of $\mathrm{N}_{2}$ bubbling, the yields of cleavage products were gradually increased over time until they plateaued after 1 hour. This observation suggested that dissolved oxygen is an efficient reactant for $\mathrm{Fe}^{2+}$ ion-mediated DNA cleavage reaction.

Inhibition of Cleavage by Scavengers. Various scavengers were tested for the identification of ROS that participate in $\mathrm{Fe}^{2+}$-mediated DNA cleavage in the presence and absence of $\mathrm{H}_{2} \mathrm{O}_{2}$ (Figures 3(a) and 3(b), respectively). The scavengers used in this work were glycerol, sodium azide, catalase, and SOD, which are known to suppress the actions of the ' $\mathrm{OH}, \mathrm{H}_{2} \mathrm{O}_{2}$, singlet oxygen, and superoxide radical, respectively. In this experiment, the efficiencies with which these scavengers inhibit radicals are not discussed due to the variation in scavenging capacities and loading concentrations. The addition of all scavengers exhibited similar inhibitory effects on the cleavage reactions, regardless of the $\mathrm{H}_{2} \mathrm{O}_{2}$ existence, indicating that all ROS namely, the ${ }^{\circ} \mathrm{OH}$, superoxide radical, singlet oxygen and $\mathrm{H}_{2} \mathrm{O}_{2}$, may participate equally in $\mathrm{Fe}^{2+}$-mediated cleavage both in the absence and presence of $\mathrm{H}_{2} \mathrm{O}_{2}$. Under Fenton conditions, it is known that both hydroxyl and superoxide radical participate in the DNA

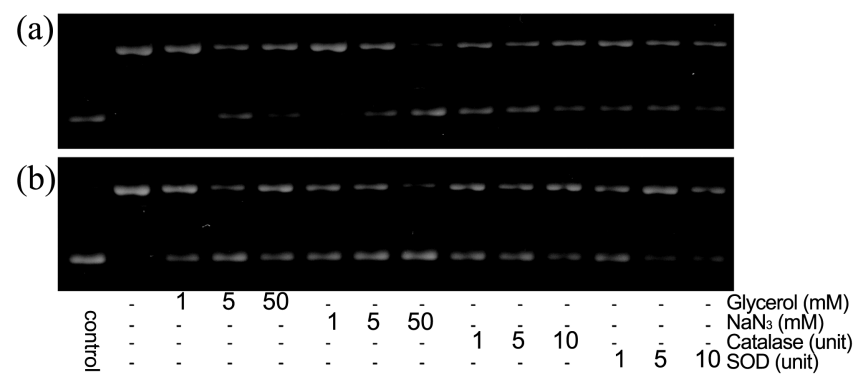

Figure 3. Effect of scavengers on pBR322 plasmid DNA cleavage in the (a) absence and (b) presence of $1.0 \mathrm{mM} \mathrm{H}_{2} \mathrm{O}_{2}$. Plasmid DNA $\left(200 \mathrm{ng}\right.$ ) was treated by $0.2 \mathrm{mM}$ of $\mathrm{FeCl}_{2}$ in $20 \mathrm{mM}$ phosphate buffer, $\mathrm{pH}$ 7.0. All samples were incubated in ice for 30 minutes. 
(a) $\mathrm{pH} 5.4$ $\mathrm{pH} 7.0$ $\mathrm{pH} 9.0$

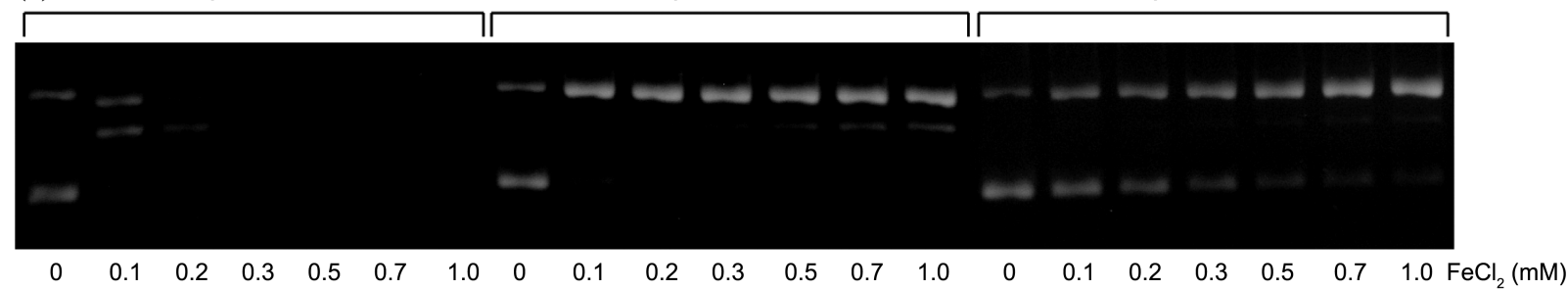

(b) pH 5.4 $\mathrm{pH} 7.0$ $\mathrm{pH} 9.0$

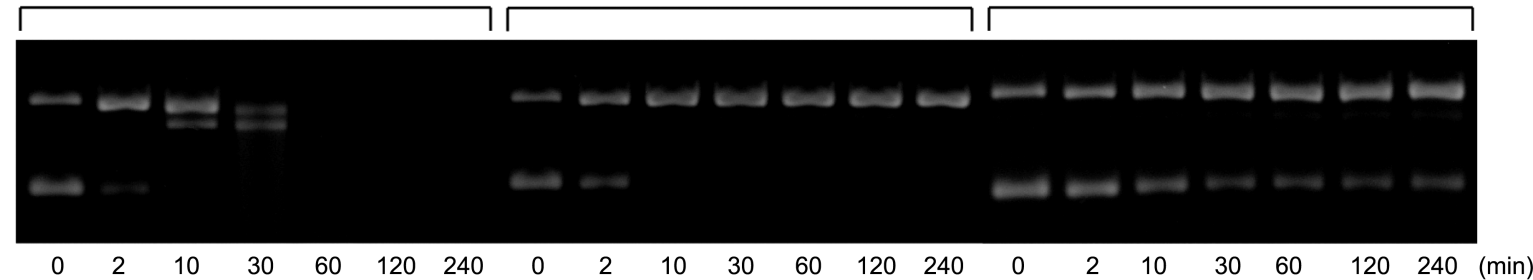

Figure 4. (a) Effect of $\mathrm{pH}$ on $\mathrm{Fe}^{2+}$-induced pBR322 plasmid DNA cleavage in the absence of $\mathrm{H}_{2} \mathrm{O}_{2}$. All experiments were performed in 20 $\mathrm{mM}$ phosphate buffers with different $\mathrm{pHs}$ prepared as described in the experimental part. $\mathrm{FeCl}_{2}$ concentration was increased as indicated. All samples were incubated at $37{ }^{\circ} \mathrm{C}$ for 30 minutes. (b) Time-dependent pBR322 plasmid DNA cleavage at various $\mathrm{pHs}$ in the absence of $\mathrm{H}_{2} \mathrm{O}_{2}$. The samples were incubated at $37^{\circ} \mathrm{C}$ and the reaction stopped at the indicated time. $\left[\mathrm{FeCl}_{2}\right]=1.0 \mathrm{mM}$.

cleavage mechanism, although superoxide radical does not attack DNA directly. 6,7

pH-dependence of pBR322 Cleavage. It has been reported that $\mathrm{Fe}^{2+}$, although stable at acidic $\mathrm{pH}$, is rapidly autoxidized to $\mathrm{Fe}^{3+}$ at a neutral and alkaline $\mathrm{pH} \cdot{ }^{15,31,32}$ Therefore, the solution $\mathrm{pH}$ was expected to affect the cleavage. Figure 4(a) shows the $\mathrm{pH}$-dependent pBR322 plasmid DNA cleavage produced by $\mathrm{Fe}^{2+}$ ion. All reaction mixtures were incubated at $37{ }^{\circ} \mathrm{C}$ for 24 hours with various $\mathrm{Fe}^{2+}$ ion concentrations to maximize the differences. Without $\mathrm{Fe}^{2+}$, solution $\mathrm{pH}$ did not induce significant nicking or cleavage of the plasmid DNA. At a glance, it is notable that the cleavage efficiency was much higher under acidic conditions, although both the open circular and linearized products were generated at all three pHs. The cleavage efficiencies depended largely on the $\mathrm{Fe}^{2+}$ concentration at all $\mathrm{pHs}$. Supercoiled DNA was completely cleaved after 24 hours of incubation under acidic conditions, even at the lowest $\mathrm{Fe}^{2+}$ concentration $(0.1 \mathrm{mM})$. At $\mathrm{Fe}^{2+}$ concentrations above 0.3 $\mathrm{mM}$, no band was observed as all plasmid DNA was seemingly cleaved to smaller pieces. The cleavage efficiency was decreased with increasing $\mathrm{pH}$. Increasing the $\mathrm{Fe}^{2+}$ concentration at $\mathrm{pH} 7.0$ resulted in a gradual decrease of the supercoiled form up to $\mathrm{Fe}^{2+}$ concentration of $0.5 \mathrm{mM}$. However, there was no sign of DNA fragmentation, indicating that the majority of plasmid DNA remained in either the open circular or linearized form. At a higher $\mathrm{pH}$, the supercoiled form remained up to $1.0 \mathrm{mM} \mathrm{Fe}^{2+}$, due to a significant decrease in cleavage ability. Here, the majority of plasmid DNA remained in the open circular form, while only a small amount of supercoiled and linearized forms was observed.

Time-dependent cleavage reactions at three $\mathrm{pH}$ conditions with $1.0 \mathrm{mM}$ of $\mathrm{Fe}^{2+}$ were also performed in Figure 4(b). At all $\mathrm{pHs}$, the supercoiled form was cleaved to open circular and linear forms. The cleavage rate increased with decreas- ing $\mathrm{pH}$. At $\mathrm{pH} 5.4$, the supercoiled form completely disappeared at 10 minutes and band smearing appeared at 30 minutes. After 1 hour of reaction, all bands disappeared and even the band smearing became faint, indicating that small DNA fragments were cleaved to pieces of nucleotides. Finally after 2 hours of reaction, neither bands corresponding to DNA itself nor that representing smeared DNA were observed. At pH 7.0, the supercoiled form was completely cleaved to open circular and small linear forms at 30 minute of reaction. After this time, no significant change was observed: the majority remained as the open circular form and minority as the linear form. At the highest $\mathrm{pH}$, some of the supercoiled from remained even after 4 hours, after which no further significant change occurred.

Fluorescence Detection of ${ }^{\circ} \mathrm{OH}$ Generation. The ${ }^{\circ} \mathrm{OH}$ has been proposed as the active radical species in the $\mathrm{Fe}^{2+}$ mediated DNA cleavage reaction. Therefore, the generation of ${ }^{\circ} \mathrm{OH}$ by $\mathrm{Fe}^{2+}$ at various concentrations was tested using the fluorescence method. The fluorescence measurement uses the $\mathrm{OH}$-induced conversion of non-fluorescent TPA to highly fluorescent 2-hydroxy-terephthalate (TPA-OH) ${ }^{32}$ $\mathrm{Fe}^{2+}$ concentration-dependent ${ }^{\circ} \mathrm{OH}$ generations in the presence and absence of $\mathrm{H}_{2} \mathrm{O}_{2}$ in $\mathrm{H}_{2} \mathrm{O}$ and in $5 \mathrm{mM}$ phosphate buffer were compared in Figure $5 \mathrm{a}$. In both cases, the ${ }^{\circ} \mathrm{OH}$ generation in $5 \mathrm{mM}$ phosphate buffer solution appeared to be fairly $\mathrm{Fe}^{2+}$ concentration-dependent while it was almost negligible in $\mathrm{H}_{2} \mathrm{O}$. In phosphate buffer, the ${ }^{\circ} \mathrm{OH}$ generation was far more efficient in the presence of $\mathrm{H}_{2} \mathrm{O}_{2}$ than in its absence. The fluorescence intensity of TPA-OH in the presence of $\mathrm{H}_{2} \mathrm{O}_{2}$ was about 9-fold higher than its absence at $10 \mu \mathrm{M}$ of $\mathrm{Fe}^{2+}$ and about 5-fold higher at $200 \mu \mathrm{M}$ of $\mathrm{Fe}^{2+}$. The $\mathrm{H}_{2} \mathrm{O}_{2}$ concentration and the $\mathrm{pH}$ may also affect the $\cdot \mathrm{OH}$ generation. Thus, the TPA-OH-originated fluorescence intensity was compared at various $\mathrm{H}_{2} \mathrm{O}_{2}$ concentrations at three different pHs (Figure 5(b)). The increase in the $\mathrm{H}_{2} \mathrm{O}_{2}$ 

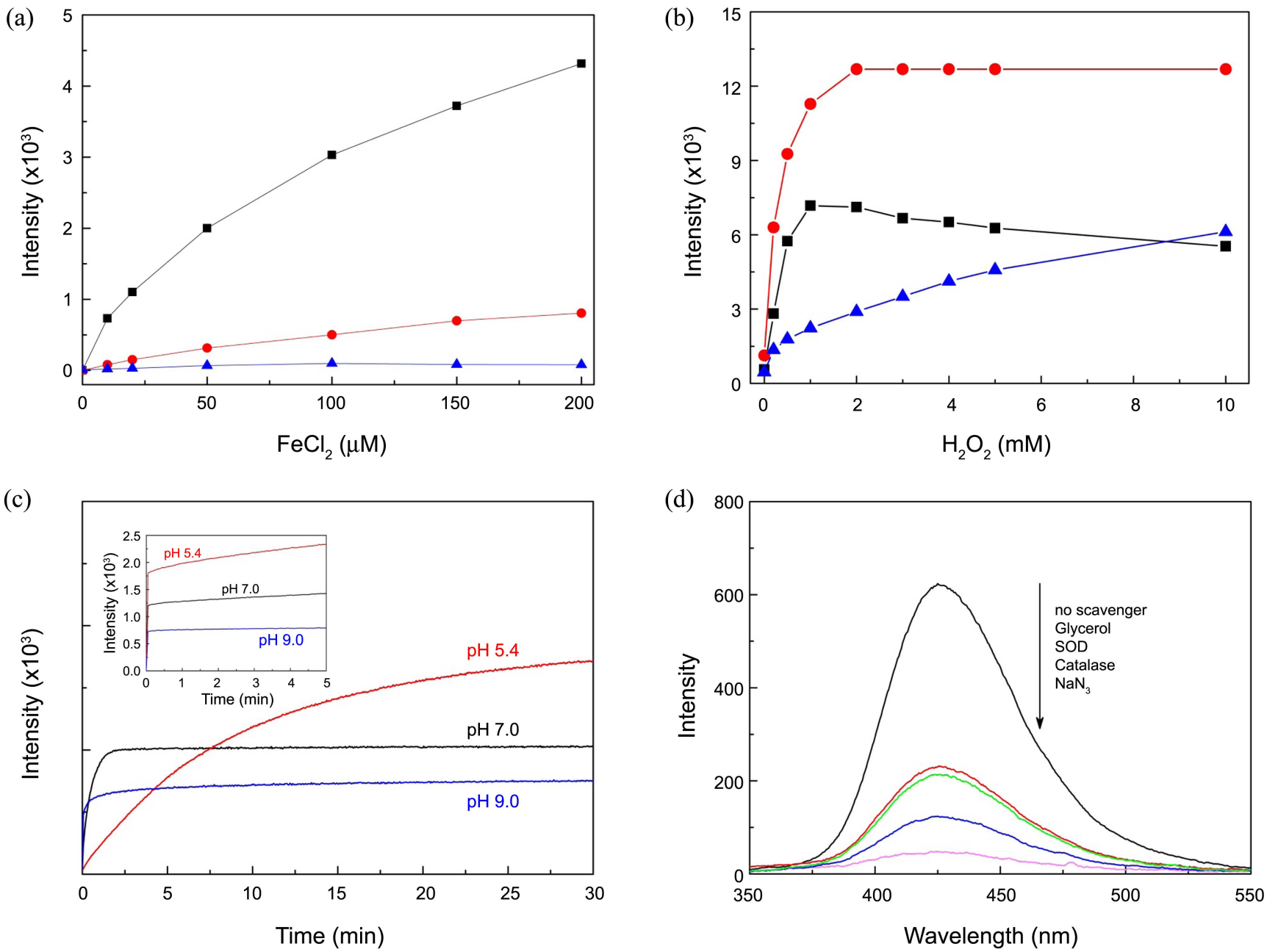

Figure 5. (a) $\mathrm{FeCl}_{2}$ concentration-dependent fluorescence intensity due to the formation of TPA-OH in $20 \mathrm{mM}$ of phosphate buffer in the

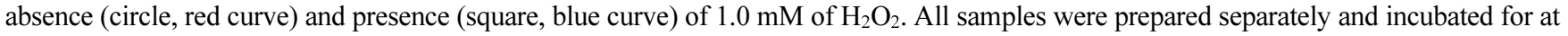
least 6 hours to ensure reaction completion. (b) $\mathrm{H}_{2} \mathrm{O}_{2}$ concentration-dependent TPA-OH generation at pH 5.4 (red), 7.0 (black) and 9.0 (blue). $\left[\mathrm{FeCl}_{2}\right]=100 \mu \mathrm{M},\left[\mathrm{H}_{2} \mathrm{O}_{2}\right]=0,0.2,0.5,1.0,1.5,2.0,3.0,4.0,5.0$ and $10 \mathrm{mM}$. (c) Time-dependent fluorescence change of TPA-OH in $5 \mathrm{mM}$ of phosphate buffer at various $\mathrm{pHs}$. $\left[\mathrm{FeCl}_{2}\right]=100 \mu \mathrm{M}$. Insert: time-dependent fluorescence change of TPA-OH in the presence of 1 $\mathrm{mM}$ of $\mathrm{H}_{2} \mathrm{O}_{2}$ under the same condition. (d) Inhibition of ${ }^{\circ} \mathrm{OH}$ generation by various scavengers in the absence of $\mathrm{H}_{2} \mathrm{O}_{2}$ at $\mathrm{pH} 7.0$. Reaction mixtures were incubated at room temperature for at least 6 hours to ensure reaction completion. 5 units of SOD and catalase and $2 \mathrm{mM}$ of glycerol and sodium azide were used.

concentration generally induced more ${ }^{\circ} \mathrm{OH}$. The optimal $\mathrm{H}_{2} \mathrm{O}_{2}$ concentrations appeared to be dependent on the $\mathrm{pH}$ of the medium, in this particular case, phosphate buffer. At $\mathrm{pH}$ 5.4, the increasing fluorescence plateaued at $2 \mathrm{mM} \mathrm{H}_{2} \mathrm{O}_{2}$ and no further change was observed with increasing $\mathrm{H}_{2} \mathrm{O}_{2}$ concentration. In contrast, at $\mathrm{pH} 7.0$, the maximum appeared at $1.0 \mathrm{mM}$ of $\mathrm{H}_{2} \mathrm{O}_{2}$, followed by a slight decrease with further increasing $\mathrm{H}_{2} \mathrm{O}_{2}$ concentration. At $\mathrm{pH} 9.0$, the ${ }^{\circ} \mathrm{OH}$ generation appeared to be less efficient. The fluorescence intensity increased gradually up to $10 \mathrm{mM}$ of $\mathrm{H}_{2} \mathrm{O}_{2}$ addition. According to the previous report, the optimal $\mathrm{H}_{2} \mathrm{O}_{2}$ concentration for ${ }^{\circ} \mathrm{OH}$ generation was determined to be $\sim 2.5$ $\mathrm{mM}$, but excess $\mathrm{H}_{2} \mathrm{O}_{2}$ scavenged ${ }^{\circ} \mathrm{OH}$ (Eq. 3), based on the observation of in vivo cellular survival and cellular DNA damage production experiments. ${ }^{8}$ This phenomenon is similar with the result obtained at $\mathrm{pH} 7$ in our experiment. Considering the results, the lower $\mathrm{pH}$ was preferred in the
$\mathrm{Fe}^{2+}$-mediated ${ }^{\circ} \mathrm{OH}$ generation. This may be related to the low pH-preferable plasmid DNA cleavage (Figure 4a).

Time-dependent TPA-OH generation at different $\mathrm{pHs}$ both in the presence and absence of $\mathrm{H}_{2} \mathrm{O}_{2}$ in $5 \mathrm{mM}$ of phosphate buffers was also measured in Figure 5(c). In the absence of $\mathrm{H}_{2} \mathrm{O}_{2}$, low $\mathrm{pH}$ produced more ${ }^{\circ} \mathrm{OH}$, which is well consistent with the $\mathrm{pH}$ dependent plasmid DNA cleavage. But the reaction rates were turned out to be in reverse: higher $\mathrm{pH}$ showed faster reaction. In the presence of $\mathrm{H}_{2} \mathrm{O}_{2}$, the ${ }^{\circ} \mathrm{OH}$ generation efficiencies showed same $\mathrm{pH}$ dependent with those in its absence. The ${ }^{\circ} \mathrm{OH}$ generation is composed with two distinctive reactions independent of the buffer $\mathrm{pH}$; very fast ones terminated in few seconds and very slow ones last for several hours and this trend is much clear at lower pHs. Although the initial rates are too fast to compare with each other, the slower ones seem to be similar with the overall reaction rates in the absence of $\mathrm{H}_{2} \mathrm{O}_{2}$ : lower $\mathrm{pH}$ exhibits 

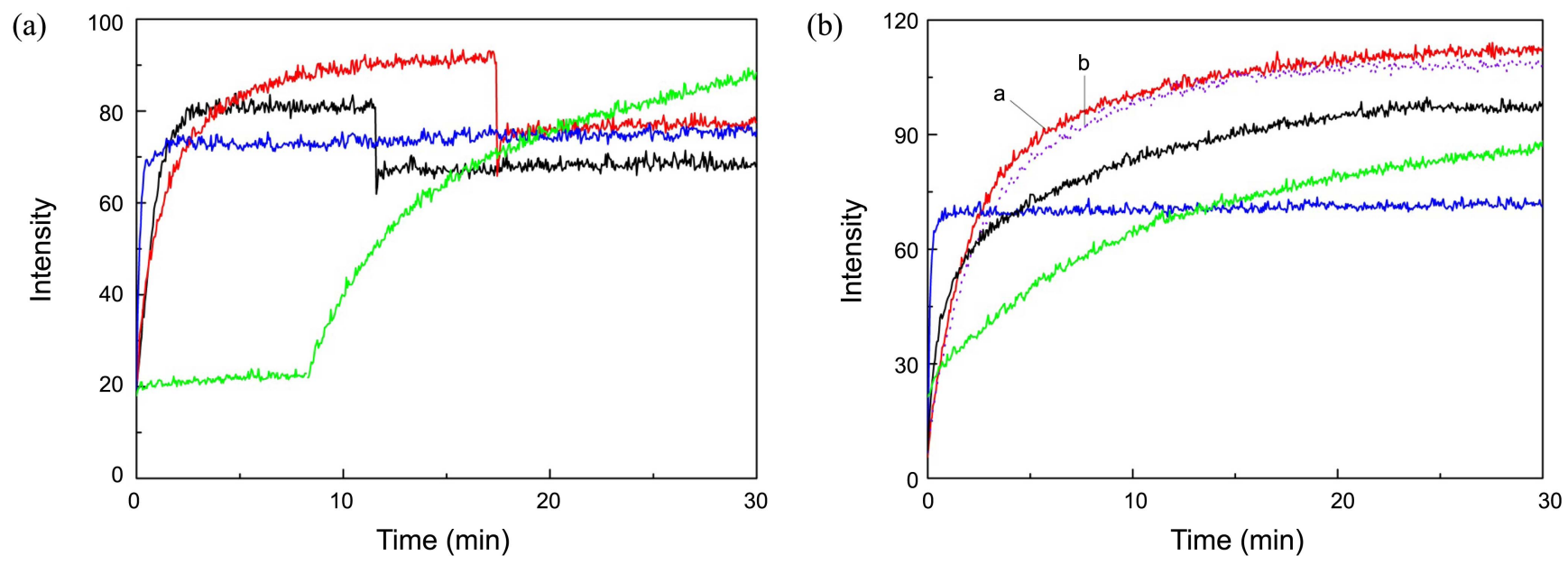

(c) phosphate carbonate cacodylate

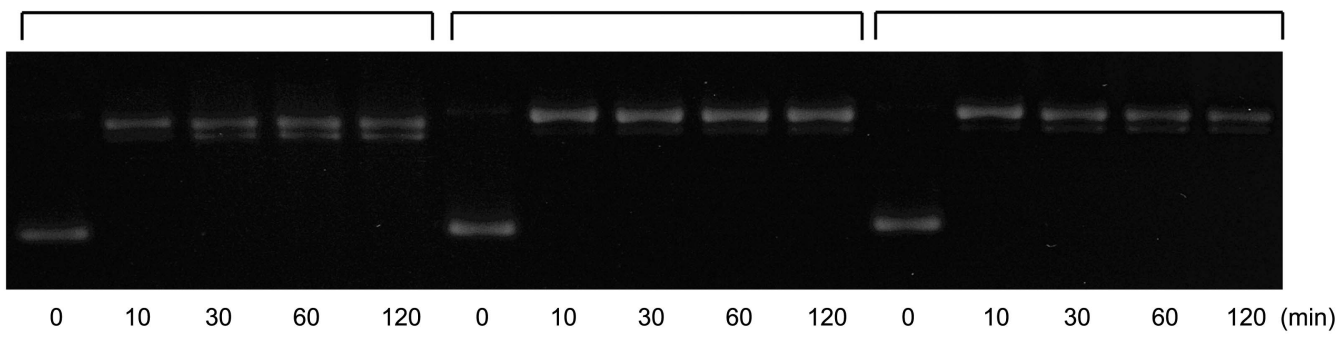

Figure 6. (a) Time-dependent fluorescence change of TPA-OH in $5 \mathrm{mM}$ of phosphate (red curve), bicarbonate (black), and cacodylate (green) buffers and in $\mathrm{H}_{2} \mathrm{O}$ with $100 \mu \mathrm{M}$ of ctDNA (blue). The reactions were started by the addition of $100 \mu \mathrm{M}$ of $\mathrm{FeCl}_{2}$. When the fluorescence intensities were stabilized, $100 \mu \mathrm{M}$ of ctDNA was added and the changes in the fluorescence intensity were continuously recorded. In the case of $\mathrm{H}_{2} \mathrm{O}$, ctDNA was included prior to the reaction start. (b) Time-dependent fluorescence change of TPA-OH in $5 \mathrm{mM}$ phosphate (red, curve a), bicarbonate (black), and cacodylate (green) buffers and $\mathrm{H}_{2} \mathrm{O}$ (blue) in the presence of $100 \mu \mathrm{M}$ of ctDNA. For comparison, $5 \mathrm{mM}$ of phosphate (dotted violet curve marked by $\mathrm{b}$ ) in the absence of ctDNA was also measured. Reactions were started by the addition of $100 \mu \mathrm{M}$ of $\mathrm{FeCl}_{2}$. (c) Time-dependent pBR322 plasmid DNA cleavage in different buffers. Buffer concentrations were 5 $\mathrm{mM}$, at $\mathrm{pH} 7.0$ and $37^{\circ} \mathrm{C}$.

slower reaction.

The presence of various scavengers may inhibit the generation of ${ }^{\circ} \mathrm{OH}$, which would decrease the fluorescence intensity of TPA-OH. The fluorescence spectra of TPA-OH in the presence of various scavengers in the absence of $\mathrm{H}_{2} \mathrm{O}_{2}$ are depicted in Figure 5(d). All the radical scavengers decreased the fluorescence intensity, suggesting that the ${ }^{\circ} \mathrm{OH}$ generation was suppressed by the presence of scavengers, indicating that the superoxide radical, $\mathrm{H}_{2} \mathrm{O}_{2}$, as well as singlet oxygen may participate in the process of ${ }^{\circ} \mathrm{OH}$ generation. The same trend was observed in the presence of $\mathrm{H}_{2} \mathrm{O}_{2}$ (data not shown), indicating that the mechanism behind the ${ }^{\circ} \mathrm{OH}$ generation reaction is unaffected by the presence of $\mathrm{H}_{2} \mathrm{O}_{2}$.

Buffer Components and DNA Effect on ${ }^{\circ} \mathrm{OH}$ Generation and DNA Cleavage. The buffer components have been reported to be critical in the $\mathrm{Fe}^{2+}$-mediated DNA cleavage and $\mathrm{OH}$ radical generation, ${ }^{23,32}$ as well as in the oxidation of $\mathrm{Fe}^{2+} \cdot{ }^{4,37}$ The increase in the phosphate or bicarbonate buffer concentration has been reported to enhance both the ${ }^{\circ} \mathrm{OH}$ generation and DNA cleavage efficiency. Consequently, the involvement of a new intermediate, 'crypto- ${ }^{-O H}$ ', which may originate from the ${ }^{\circ} \mathrm{OH}-\mathrm{Fe}-$ buffer component complex, in the cleavage process was proposed. Here, we assayed the similar buffer effect on the $\mathrm{Fe}^{2+}$-mediated ${ }^{\circ} \mathrm{OH}$ generation and pBR322 plasmid DNA cleavage in the absence of $\mathrm{H}_{2} \mathrm{O}_{2}$. In Figure 6(a) shows a time-dependent increase in the fluorescence intensity upon TPA-OH generation, which was induced by the addition of $\mathrm{Fe}^{2+}$ to three different buffer systems and in water. For the control experiment, when $\mathrm{Fe}^{2+}$ and TPA were mixed with $\mathrm{H}_{2} \mathrm{O}$, no significant fluorescence change was observed (data not shown). In the absence of any buffering compounds when $\mathrm{H}_{2} \mathrm{O}_{2}$ was present, the fluorescence intensity increased very rapidly: the increase peaked within two minutes, suggesting the rapid formation of TPA-OH. The presence of buffering compounds namely, phosphate or bicarbonate ions, reduced the rate of the TPA$\mathrm{OH}$ generation. In the cacodylate buffer, the fluorescence intensity remained almost constant. Observed reductions in the reaction rates suggested the interaction of buffering compound with $\mathrm{Fe}^{2+}$. In a comparison of the phosphate and bicarbonate buffers, the former exhibited higher fluorescence intensity than the latter, which is consistent with a previous report. ${ }^{32} \mathrm{OH}$ generation was faster in bicarbonate buffer, reaching completion within several minutes, than in phosphate, in which it lasted for about 20 minutes. In these two buffer cases, the addition of $100 \mu \mathrm{M}$ of ctDNA induced 
significant decreases in the fluorescence intensity followed by a slight increase. The decrease was the result of dilution by addition of DNA solution. In contrast, the fluorescence intensity was dramatically increased by the addition of ctDNA in the cacodylate buffer.

The time-dependent increases in the fluorescence intensity upon formation of TPA-OH in various buffers in the presence of ctDNA are depicted in Figure 6(b). The reactions were initiated by the addition of $\mathrm{Fe}^{2+}$ to various buffer solutions containing ctDNA and TPA. The increases in fluorescence intensity in the phosphate and bicarbonate became slower than that observed in the absence of DNA (Figure 6(a)). In the cacodylate case, the profile of the increase in the fluorescence intensity resembled that when ctDNA was either initially present (Figure 6(b), green curve) or added during the reaction process (Figure 6(a), green curve). This observation suggested that the number of $\mathrm{Fe}^{2+}$ ions participating in the hydroxyl generation reaction was unaffected by whether ctDNA was initially present or added during the process, implying that either all $\mathrm{Fe}^{2+}$ binding sites of ctDNA were pre-occupied by cacodylate or cacodylate does not prevent the $\mathrm{Fe}^{2+}$ binding to DNA due to its very weak interaction with $\mathrm{Fe}^{2+}$. The buffer component-dependent plasmid DNA cleavage reaction was carried out and the results are depicted in Figure 6(c). All three buffers exhibited efficient cleavage of supercoiled DNA. The linearized component was also observed, even at 10 minutes of reaction time. Of the buffer components, phosphate buffer showed the highest cleavage efficiency: production of the linear component was the most effective. Bicarbonate and cacodylate showed similar cleavage efficiencies. In the case of cacodylate, the cleavage efficiency is very similar with the same experiment performed in water without any buffering system (data not shown).

\section{Discussion}

Comparison of $\mathrm{Fe}^{2+}$-induced DNA Cleavage in the Presence and Absence of $\mathrm{H}_{2} \mathrm{O}_{2}$. Some studies reported that molecular oxygen is involved in $\mathrm{Fe}^{2+}$-induced DNA cleavage $^{23}$ and ${ }^{\circ} \mathrm{OH}$ generation ${ }^{33}$ in the absence of $\mathrm{H}_{2} \mathrm{O}_{2}$, indicating that the molecular oxygen may act as the molecular source of ROS. The fact that nitrogen bubbling significantly suppressed the DNA cleavage efficiency (Figure 2), which was also consistent with prior reports, implied the production of the ROS by the molecular oxygen. The efficiency and the reaction rate of the DNA cleavage do not necessarily reflect the $\mathrm{H}_{2} \mathrm{O}_{2}$-originated generation of ${ }^{\circ} \mathrm{OH}$. The rate and efficiency of the DNA cleavage in the absence of $\mathrm{H}_{2} \mathrm{O}_{2}$ were both higher than those in its presence (Figure 1). On the other hand, ${ }^{\circ} \mathrm{OH}$ generation was more efficient in the presence of $\mathrm{H}_{2} \mathrm{O}_{2}$ (Figure 5). These observations suggested the presence of two pathways in regard to the existence of $\mathrm{H}_{2} \mathrm{O}_{2}$. The first appeared dominant in the presence of $\mathrm{H}_{2} \mathrm{O}_{2}$. $\mathrm{Fe}^{2+}$ may form a complex with $\mathrm{H}_{2} \mathrm{O}_{2}$ so that the cleavage reaction would follow the Fenton mechanism as shown in Eqs. (2) and (3). In contrast, the appeared dominant in the absence of
$\mathrm{H}_{2} \mathrm{O}_{2} ; \mathrm{Fe}^{2+}$ complexed with buffer components, which, in turn, may have interacted with molecular oxygen and used it as a substrate for ROS production. It has been proposed that the biologically active oxygen radical is not the free hydroxyl radial but the "crypto- $\mathrm{OH}$ ", $8,32,34$ which explains the low efficiencies in ${ }^{\circ} \mathrm{OH}$ generation when the reaction was performed in water without any buffer components.

From the effect of the scavengers on the DNA cleavage reaction, which are shown in Figures 3(a) and 3(b), the same ROS were detected irrespective of the presence of $\mathrm{H}_{2} \mathrm{O}_{2}$. In addition, a similar inhibitory effect was observed in ${ }^{\circ} \mathrm{OH}$ generation (Figure 5(d)). All these observations led us to conclude that the ${ }^{\circ} \mathrm{OH}$, superoxide radical, $\mathrm{H}_{2} \mathrm{O}_{2}$, and singlet oxygen were produced during the process of $\mathrm{Fe}^{2+}$ oxidation both in the presence and absence of $\mathrm{H}_{2} \mathrm{O}_{2}$. These results are in agreement with the previous proposal in which the Fenton mechanism can be evoked from the direct interaction between $\mathrm{Fe}^{2+}$ and molecular oxygen through Eqs. (6) and (8)..$^{15,35}$

$$
\begin{aligned}
& {\left[\mathrm{Fe}^{2+}\left(\mathrm{HPO}_{4}^{2-}\right)_{n}\right]^{(2-n)}+\mathrm{O}_{2} \rightarrow\left[\mathrm{Fe}^{3+}\left(\mathrm{HPO}_{4}^{2-}\right)_{n}\right]^{(3-n)}+\mathrm{O}_{2}{ }^{--} }(6) \\
& 2 \mathrm{O}_{2}{ }^{--}+ 2 \mathrm{H}^{+} \rightarrow \mathrm{O}_{2}+\mathrm{H}_{2} \mathrm{O}_{2} \\
& \mathrm{O}_{2}{ }^{--}+\mathrm{H}_{2} \mathrm{O}_{2} \stackrel{\mathrm{Fe}^{2+}}{\longrightarrow}{ }^{1} \mathrm{O}_{2}+\mathrm{OH}^{-}+{ }^{\cdot} \mathrm{OH}
\end{aligned}
$$

The steps denoted by Eqs. (6) and (7) are highly pHdependent. Saran et al. conducted $\mathrm{pH}-\mathrm{dependent}{ }^{\circ} \mathrm{OH}$ generation in phosphate buffers by monitoring the fluorescence change of TPA and found that the most appropriate $\mathrm{pH}$ value was 6.3 , while the efficiency was decreased by adjusting the $\mathrm{pH}$ values. ${ }^{32}$ Meanwhile, Svoboda et al. measured the $\mathrm{pH}-$ dependent autoxidation efficiency of $\mathrm{Fe}^{2+}$ in tris-maleate buffer. ${ }^{15}$ They observed that the autoxidation efficiency was increased with increasing the $\mathrm{pH}$ in the $\mathrm{pH}$ range 6.8-8.1. In our experiments, however, both ${ }^{\circ} \mathrm{OH}$ generation and DNA cleavage efficiencies showed the same $\mathrm{pH}$ dependency in the presence and absence of $\mathrm{H}_{2} \mathrm{O}_{2}$ : both reactions were preferable at acidic $\mathrm{pH}$. These results seem to support Eqs. (6) and (7). As aforementioned, the time-dependent ${ }^{\circ} \mathrm{OH}$ generation at different $\mathrm{pHs}$ (Figure 5(c)), the reaction rate, and the efficiency did not exhibit consistent trends. The reaction rate was maximized at the highest $\mathrm{pH}$, while the ' $\mathrm{OH}$ yield was highest at the lowest $\mathrm{pH}$. On the other hand, both reaction rate and efficiency presented similar trend in the cleavage reaction. This discrepancy suggests that the 'OH may not be the only oxygen species responsible for DNA cleavage.

pH Dependency of DNA Cleavage and ' $\mathrm{OH}$ Generation. Previous studies observed that the autoxidation of $\mathrm{Fe}^{2+}$ has a strong $\mathrm{pH}$ dependency in phosphate buffer, resulting in the production of $\mathrm{O}_{2}{ }^{--}$through the reaction shown in Eqs. (6)(7). ${ }^{15,36}$ According to the reports, the formation of $\mathrm{Fe}^{3+}$ via the autoxidation was markedly increased with increasing $\mathrm{pH}$, over the $\mathrm{pH}$ range 6.8-8.1. They attributed the $\mathrm{pH}$ effect on the catalytic activity to the increased binding constant of $\mathrm{Fe}^{2+}$ with $\mathrm{HPO}_{4}{ }^{2-}\left(3981 \mathrm{M}^{-1}\right)$ compared to that with $\mathrm{H}_{2} \mathrm{PO}_{4}{ }^{-}$ $\left(501 \mathrm{M}^{-1}\right),{ }^{37}$ because the ratio between $\left[\mathrm{HPO}_{4}{ }^{2-}\right] /\left[\mathrm{H}_{2} \mathrm{PO}_{4}{ }^{-}\right]$ 

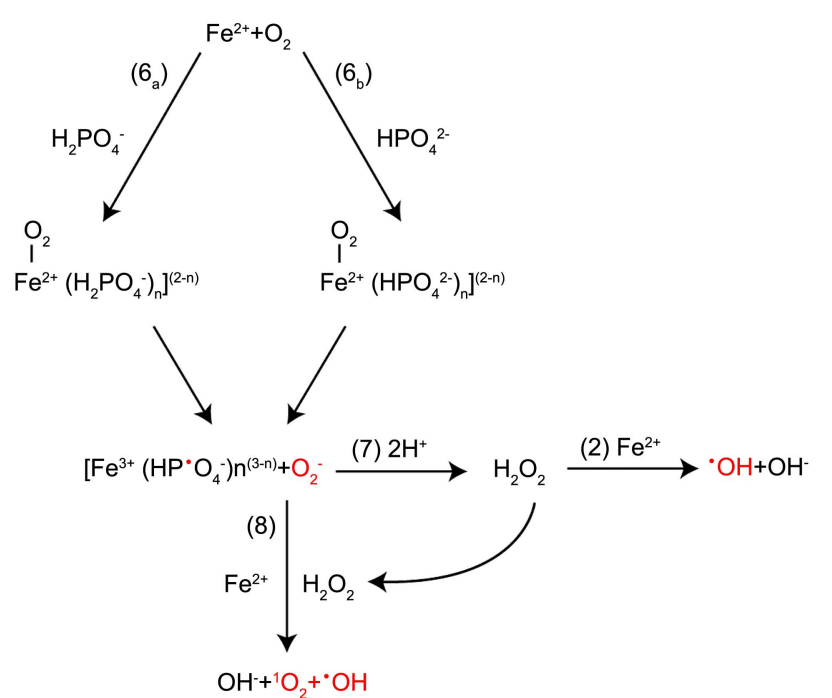

Scheme 1. Proposed $\mathrm{Fe}^{2+}$ autoxidation-induced DNA cleavage mechanism. Numbers indicate the equation cited in the text.

increased from 1.0 at $\mathrm{pH} 7.2$ to 2.5 at $\mathrm{pH}$ 7.6. In our paper, we performed the ${ }^{\circ} \mathrm{OH}$ generation and DNA cleavage reactions in phosphate buffer at three different $\mathrm{pHs}$ : 5.4, 7.0, and 9.0. However, the observed $\mathrm{pH}$ dependencies exhibited exactly the opposite trends to those observed in the iron autoxidation: both DNA cleavage and ${ }^{\circ} \mathrm{OH}$ generation were predominant at decreasing $\mathrm{pH}$. This discrepancy suggests that the action of at least two stepwise processes: the first step, responsible for the generation of $\mathrm{O}_{2}{ }^{\cdot-}$ via autoxidation of iron, which is denoted as process $6_{a}$ or $6_{b}$ in the Scheme 1 ; and the second step for the production of $\mathrm{H}_{2} \mathrm{O}_{2}$ and ${ }^{\circ} \mathrm{OH}$, through process 7 and 2 or 8 known as Haber-Weiss reaction. Thus, our results suggested that the first process may be preferred at higher $\mathrm{pH}$ for producing $\mathrm{O}_{2}{ }^{--}$by iron autoxidation with the help of $\mathrm{HPO}_{4}{ }^{2-}$ binding, while the second process seems to be preferred at low $\mathrm{pH}$ due to the requirement of two equivalents of protons. This conclusion is supported by the slow rate of ${ }^{\circ} \mathrm{OH}$ production at lower $\mathrm{pH}$ (Figure 5(c)), whereas the efficiency was higher. At high $\mathrm{pH}$, $\mathrm{O}_{2}{ }^{-}$can be generated quickly but the continuing process to generate ${ }^{\circ} \mathrm{OH}$ was prevented by the low concentration of available protons in the aqueous solution.

Buffer Component and DNA Effect. It is proposed that the complexation of $\mathrm{Fe}^{2+}$ ions and chelating agents, which include not only DNA moieties but also buffer components, enhanced the $\mathrm{Fe}^{2+}$ oxidation or ${ }^{\circ} \mathrm{OH}$ generation in the absence of $\mathrm{H}_{2} \mathrm{O}_{2}{ }^{15,23,32,35,38}$ Of these chelating agents, DNA has been reported to be the most efficacious for $\mathrm{Fe}^{2+}$ oxidation. In this paper, phosphate, bicarbonate, and cacodylate buffer components were tested for their capability in ${ }^{\circ} \mathrm{OH}$ generation and DNA cleavage (Figures 6(a), 6(b), and 6(c)). Similarly with the previous observations, the efficiencies of both ${ }^{\circ} \mathrm{OH}$ generation and DNA cleavage were higher in phosphate buffer than in bicarbonate, although the reaction rates seemed to be similar. However, in the case of cacodylate buffer, negligible change was observed, and the addition of $100 \mu \mathrm{M}$ of ctDNA rapidly increased the ${ }^{\circ} \mathrm{OH}$ generation (Figure 6(a)). This indicates either that cacodylate buffer is a poor ligand to $\mathrm{Fe}^{2+}$ for ${ }^{\circ} \mathrm{OH}$ generation or that there might be no interaction between $\mathrm{Fe}^{2+}$ and cacodylate buffer component.

In the comparison of time-dependent ${ }^{\circ} \mathrm{OH}$ generation in the presence of ctDNA with various buffer components, $\mathrm{H}_{2} \mathrm{O}$ showed the fastest initial rate, while the presence of buffering compounds slowed the generation (Figure 6(a) and (b)), suggesting that DNA itself may be the best chelating agent for $\mathrm{Fe}^{2+}$ (DNA cleavage reaction was also performed in $\mathrm{H}_{2} \mathrm{O}$ and the cleavage efficiency was comparable with the case in other buffers, data not shown). The presence of buffer components slowed the ${ }^{\circ} \mathrm{OH}$ generation compared to their absence, indicating that these buffer components may also compete with DNA for $\mathrm{Fe}^{2+}$ binding.

DNA Cleavage Mechanism by $\mathrm{Fe}^{2+}$ Autoxidation. The rate of ${ }^{\circ} \mathrm{OH}$ generation decreased with decreasing $\mathrm{pH}$ in the absence of $\mathrm{H}_{2} \mathrm{O}_{2}$, while the reaction efficiency was higher at lower pHs. This discrepancy can be explained by assuming two different $\mathrm{pH}$-dependent pathways. As discussed above in the section on $\mathrm{pH}$ dependency, the autoxidation of iron with the production of superoxide radicals (process $6_{a}$ or $6_{b}$ in the Scheme 1) and ${ }^{\circ} \mathrm{OH}$ generation (process 7 and 2 or 8 ) are considered to be consecutive processes, possibly with different $\mathrm{pH}$ dependencies. In the acidic condition, $\mathrm{Fe}^{2+}$ complexes with $\mathrm{H}_{2} \mathrm{PO}_{4}{ }^{-}$and follows process 6 a. Since this process is, in fact, preferred at high $\mathrm{pH}$, the rate of superoxide radical production can be very low. However, the generated superoxide radicals can be easily converted to ${ }^{\circ} \mathrm{OH}$ due to low $\mathrm{pH}$ preference. On the other hand, $\mathrm{Fe}^{2+}$ may form a complex with $\mathrm{HPO}_{4}{ }^{2-}$ at basic condition, and this reaction is preferable at high $\mathrm{pH}$, resulting in the high yield of the superoxide radical. However, the following process 7 requires protons to generate $\mathrm{H}_{2} \mathrm{O}_{2}$, and the other process (process 2) also prefers acidic condition because hydroxide ions can be stabilized by association with protons to make $\mathrm{H}_{2} \mathrm{O}$. Of those two processes, the second, which produces ${ }^{\circ} \mathrm{OH}$, seems to be so fast that $\mathrm{pH}$ does not affect the initial reaction rate. This hypothesis is supported by the $\mathrm{pH}-$ independent fast reaction rate of ${ }^{\circ} \mathrm{OH}$ generation in the presence of $\mathrm{H}_{2} \mathrm{O}_{2}$ (Figure 6(c), insert). Consequently, the first process (process 6) might be responsible for the overall reaction rate.

In the presence of $\mathrm{H}_{2} \mathrm{O}_{2}$, the initial reaction rate of ${ }^{\circ} \mathrm{OH}$ generation was very high at all $\mathrm{pHs}$, whereas DNA cleavage rate was much slower than in its absence. These opposing trends suggest the presence of unknown process or reactive species that is presumably independent of the ${ }^{\circ} \mathrm{OH}$ generation process. In the action of scavenger effect on DNA cleavage and ${ }^{\circ} \mathrm{OH}$ generation, it is notable that sodium azide significantly inhibits both reactions, indicating the involvement of a singlet oxygen. The singlet oxygen attacks the guanine base directly and converts it to 8-oxo-7,8-dihydro2 -deoxyguanosine (8-oxo-dG) or induces DNA cleavage, whereas the ${ }^{\circ} \mathrm{OH}$ shows nonspecific base modification. ${ }^{39-42}$ A near-IR chemiluminescence spectroscopic study reported 
that singlet oxygen can be produced via the Haber-Weiss reaction as depicted as process $8 .{ }^{43,44}$ Another study reported that radiation can convert a triplet oxygen to a singlet oxygen in the presence of metal ions, such as $\mathrm{Cu}^{+}{ }^{45}$ Thus, the singlet oxygen is a potential candidate to explain the discrepancy. The unknown process or reactive species seems to act independently of the mechanism proposed in Scheme 1, since the DNA cleavage rate was highest and the ${ }^{\circ} \mathrm{OH}$ generation lowest at low $\mathrm{pH}$. This contradiction requires explanation to complete our understanding of the $\mathrm{Fe}^{2+}$ autoxidation-mediated DNA cleavage.

Acknowledgments. This work was supported by the Korea Research Foundation (Grant no. 2009-0076930). Dr. J.-M. Kim also acknowledges the "Postdotoral Fellow Program", at Yeungnam University.

\section{References}

1. Ponka, P. Kidney Int. 1999, 55, S2.

2. Crichton, R. R.; Ward, R. J. Met. Ions Biol. Syst. 1998, 35, 633.

3. Kruszewski, M. Mut. Res. 2003, 531, 81.

4. Kakhlon, O.; Cabantchik, Z. I. Free Rad. Biol. Med. 2002, 33, 1037.

5. Mello-Filho, A. C.; Chubatsu, L. S.; Meneghini, R. Biochem. J. 1988, 256, 475 .

6. Aruoma, O. I.; Halliwell, B.; Dizdaroglu, M. J. Biol. Chem. 1989, 264, 13024.

7. Lesko, S. A.; Lorentzen, R. J.; Ts'o, P. O. P. Biochemistry 1980 , 19, 3023.

8. Imlay, J. A.; Chin, S. M.; Linn, S. Science 1988, 240, 640.

9. Beauchamp, C.; Fridovich, I. J. Biol. Chem. 1970, 245, 4641.

10. McCord, J. M.; Day, E. D., Jr. FEBS Lett. 1978, 86, 139.

11. Lloyd, D. R.; Phillips, D. H. Mut. Res. 1999, 424, 23.

12. Henle, E.; Han, Z.; Tang, N.; Rai, P.; Luo, Y.; Linn, S. J. Biol. Chem. 1999, 274, 962.

13. Pogozelski, W. K.; McNeese, T. J.; Tullius, T. D. J. Am. Chem. Soc. $1995,117,6428$.

14. Floyd, R. A. Biochemical and Biophysical Research Communications 1981, 99, 1209.

15. Svoboda, P.; Harms-Ringdahl, M. Biochimica et Biophysica Acta (BBA) - General Subjects 2002, 1571, 45.

16. Gutteridge, J. M. C. Free Radical Biology and Medicine 1991, 11, 401.

17. Floyd, R. A. Archives of Biochemistry and Biophysics 1983, 225,
263.

18. Gutteridge, J. M. Free Radic. Biol. Med. 1991, 11, 401.

19. Minotti, G.; Aust, S. D. Free Radical Biology and Medicine 1987, 3,379 .

20. Qian, S. Y.; Buettner, G. R. Free Rad. Biol. Med. 1999, 26, 1447.

21. Urbañski, N. K.; Berêsewicz, A. Acta Biochim. Pol. 2000, 47, 951.

22. Koppenol, W. H.; Liebman, J. F. J. Phy. Chem. 1984, 88, 99.

23. Flemmig, J.; Arnhold, J. Eur. Biophys. J. 2007, 36, 377.

24. Giulivi, C.; Hochstein, P.; Davies, K. J. A. Free Rad. Biol. Med. 1994, 16, 123

25. Antunes, F.; Salvador, A.; Marinho, H. S.; Alves, R.; Pinto, R. E. Free Rad. Biol. Med. 1996, 21, 917.

26. Boveris, A.; Cadenas, E. Cellular Sources and Steady-state Levels of Reactive Oxygen Species. In Oxygen, Gene Expression, and Cellular Function; Clerch, L. B., Massaro, P. J., Eds.; New York: Marcel Dekker, Inc.: 1997; p 1.

27. Cabelli, D. E.; Bielski, H. J. Use of Polyaminocarboxylates as Metal Chelators. In Methods in Enzymology; Packer, L., N., G. A., Eds.; New York, Academic Press: 1990; p 116.

28. Buettner, G. R.; Doherty, T. P.; Patterson, L. K. FEBS Lett. 1983, $158,143$.

29. Brestel, E. P. Biochem. Biophys. Res. Commun. 1985, 126, 482.

30. Milligan, J. R.; Aguilera, J. A.; Ward, J. F. Radiat. Res. 1993, 133, 151.

31. Tadolini, B.; Sechi, A. M. Free Radic. Res. Commun. 1987, 4, 161.

32. Saran, M.; Michel, C.; Stettmaier, K.; Bors, W. Free Rad. Res. 2000, $33,567$.

33. Saran, M.; Summer, K. Free Radical Research 1999, 31, 429.

34. Freinbichler, W.; Tipton, K. F.; Corte, L. D.; Linert, W. Journal of Inorganic Biochemistry 2009, 103, 28.

35. Kachur, A. V.; Manevich, Y.; Biaglow, J. E. Free Radical Research 1997, 26, 399

36. Tadolini, B. Free Radic. Res. Commun. 1987, 4, 149.

37. Martell, A. E.; Smith, R. M. Critical Stability Constants; Plenum: New York, 1988; p 5, first supplement.

38. Rush, J. D.; Koppeno, W. M. FEBS Letters 1990, 275, 114.

39. Burrows, C. J.; Muller, J. G. Chem. Rev. 1998, 98, 1109.

40. Ravanat, J.-L.; Martinez, G. R.; Medeiros, M. H. G.; Di Mascio, P.; Cadet, J. Tetrahedron 2006, 62, 10709.

41. Ravanat, J.-L.; Martinez, G. R.; Medeiros, M. H. G.; Di Mascio, P.; Cadet, J. Archives of Biochemistry and Biophysics 2004, 423, 23.

42. Ravanat, J. L.; Di Mascio, P.; Martinez, G. R.; Medeiros, M. H.; Cadet, J. J. Biol. Chem. 2000, 275, 40601.

43. Khan, A. U.; Kasha, M. Proceedings of the National Academy of Sciences of the United States of America 1994, 91, 12365.

44. Ryter, S. W.; Tyrrell, R. M. Free Radic. Biol. Med. 1998, 24, 1520.

45. Song, B.; Wang, B.; Yuan, J. Talanta 2007, 72, 231. 